\title{
Etomidate attenuates hyperoxia-induced acute lung injury in mice by modulating the Nrf2/HO-1 signaling pathway
}

\author{
LIMING JIA, HONGZHONG HAO, CHUNYU WANG and JIANFENG WEI
}

Department of Anesthesiology, Shanxi Provincial People's Hospital, Taiyuan, Shanxi 030012, P.R. China

Received September 28, 2020; Accepted May 4, 2021

DOI: $10.3892 /$ etm.2021.10217

\begin{abstract}
The present study aimed to investigate the protective effects of etomidate on hyperoxia-induced acute lung injury in mice, particularly on the nuclear factor-erythroid 2-related factor 2 (Nrf2)/heme oxygenase 1 (HO-1) pathway. Fifty specific pathogen-free mice were randomly divided into the blank control, model, high oxygen exposure + low etomidate dose $\left(0.3 \mathrm{mg} \cdot \mathrm{kg}^{-1}\right)$, a high oxygen exposure + moderate etomidate dose $\left(3 \mathrm{mg} \cdot \mathrm{kg}^{-1}\right)$, and a high oxygen exposure + high etomidate dose $\left(10 \mathrm{mg} \cdot \mathrm{kg}^{-1}\right)$ groups, with ten mice allotted per group. After $72 \mathrm{~h}$, the mice were sacrificed and the lung tissues were harvested, and the wet-to-dry (W/D) ratio of the tissues was calculated. Hematoxylin-eosin staining was performed to observe the pathological changes in the lung tissues, and the lung injury score (LIS) was calculated. The mRNA and protein expression levels of Nrf2 and HO-1 were measured. The malondialdehyde (MDA), myeloperoxidase (MPO), superoxide dismutase (SOD) and catalase (CAT) levels were also measured, and interleukin (IL)-1 $\beta$, IL-6, tumor necrosis factor alpha (TNF- $\alpha$ ) and IL-10 concentrations in the bronchoalveolar lavage fluid were determined. At low and moderate doses, etomidate decreased pathological damage in the lung tissue, decreased the LIS and W/D ratio, upregulated Nrf2 and HO-1 mRNA and protein expression, decreased IL-1 $\beta$, IL-6, and TNF- $\alpha$ concentrations, increased MPO activity and IL-10 levels, suppressed the production of the oxidation product MDA, and enhanced the activities of the antioxidant enzymes CAT and SOD. Within a certain dose range, etomidate enhanced antioxidant and anti-inflammatory effects in mice, thereby decreasing lung injury induced by the chronic inhalation of oxygen at high concentrations. Furthermore, the underlying mechanism may be associate with the upregulation of the Nrf2/HO-1 signaling pathway.
\end{abstract}

\section{Introduction}

Hyperoxia-induced acute lung injury (HALI) is a type of iatrogenic pulmonary dysfunction caused by long-term exposure to

Correspondence to: Dr Liming Jia, Department of Anesthesiology, Shanxi Provincial People's Hospital, 29 Shuangtasi Street, Taiyuan, Shanxi 030012, P.R. China

E-mail: jialiming995@163.com

Key words: etomidate, hyperoxia, acute lung injury, $\mathrm{Nrf2/HO}-1$ high concentrations of oxygen, which is commonly used in the treatment of refractory hypoxemia (1). The prolonged inhalation of oxygen at high concentrations can stimulate the production of reactive oxygen species (ROS), which may lead to an imbalance in the oxidative-antioxidant system and induce a severe inflammatory response, causing HALI, which is characterized by damage to the alveolar epithelium, increased microvascular permeability, inflammatory cell infiltration, and pulmonary edema. However, it is believed that HALI cannot be prevented simply by decreasing the concentration of inhaled oxygen, particularly because the inhalation of oxygen at high concentrations is necessary to prevent hypoxemia and to lower the incidence of incision infection, postoperative nausea, and vomiting, among other conditions (2,3). Anesthesiologists require elderly patients with poor oxygen reserves, obese patients, and patients with airway constriction to inhale oxygen at high concentrations to increase the arterial partial pressure of oxygen and patient tolerance to apnea and hypopnea syndrome as well as to ensure sufficient intubation time for preventing intraoperative hypoxia in critical situations (such as before induction and during recovery) $(4,5)$. Therefore, the decrease in oxygen concentration for preventing hyperoxia-induced lung injury is not feasible in all patients. However, the contradiction between oxygen demand and lung oxygen toxicity remains unresolved.

Anti-inflammatory drugs commonly used in clinical practice remain ineffective for the prevention and treatment of HALI. Etomidate is an ultrashort-acting, hypnotic, non-barbiturate intravenous anesthetic agent. It offers advantages such as high safety, no significant accumulation, and mild effects on respiratory functions and the circulatory system. Etomidate has been reported to exert anti-stress and anti-inflammatory effects, and has also been shown to improve the symptoms of ischemia-reperfusion injury (6-11).

Nuclear factor-erythroid 2-related factor $2(\mathrm{Nrf} 2)$ is a transcription factor with antioxidant and anti-inflammatory properties that plays a key role in maintaining the endogenous redox balance and controlling the gene networks involved in cell cycle homeostasis, metabolism, cell protection, immunity and tumorigenesis (12). At present, Nrf2 is known as the primary regulator of antioxidative responses. It induces the expression of multiple genes, most of which encode antioxidant/detoxification enzymes (13) and plays a key role by inducing both antioxidants and phase II enzymes [such as NAD(P)H: Quinone oxidoreductase 1, Glutathione S-transferases (GSTs)], including heme oxygenase 1 (HO-1) (14). HO-1 is induced at high levels under stress and inflammation. HO-1 performs physiological functions 
in cell protection, inflammatory response regulation, antioxidant function, regulation of cell proliferation, angiogenesis and cardiovascular and pulmonary homeostasis. HO-1 induction is an adaptive defense mechanism that protects cells and tissues in various pathological states, such as in cardiovascular and pulmonary diseases (15). The overall beneficial role of HO-1 is primarily achieved via the $\mathrm{HO}$ system. Studies have shown that $\mathrm{H}_{2}$ supplementation can improve hyperoxic lung injury, improve blood oxygenation, and alleviate oxidative stress by regulating the Nrf2 pathway and inducing HO-1 (16). Therefore, Nrf2/HO-1 signaling plays a critical role in the regulation of oxidative stress.

In the present study, it was hypothesized that etomidate could decrease HALI through its anti-stress and anti-inflammatory action and its potential effects on the anti-inflammatory Nrf2/HO-1 pathway were explored.

\section{Materials and methods}

Animals. Fifty male specific pathogen-free mice C57BL/6 mice (6-8 weeks old; weighing 23-25 g) were provided by the Institute of Experimental Animal Research, Chinese Academy of Medical Sciences. Before the experiment, the mice were provided access to sufficient food and water, housed at a relative humidity of $40-60 \%$ and temperature of $22-25^{\circ} \mathrm{C}$, with a $12-\mathrm{h}$ day/12-h night cycle. The experimental protocol was approved by the Laboratory Animal Ethics Committee of Shanxi Provincial People's Hospital (approval no. 2019-001-05) and was in accordance with the Guide for the Care and Use of Laboratory Animals published by the National Research Council (17).

Experimental instruments. The following instruments were used: Optical microscope (Olympus Corporation); ChampGel 5000 gel imager (Beijing Sage Venture Technology Co.); ABI Prism ${ }^{\circledR} 7500$ fluorescence quantitative PCR instrument (Applied Biosystems; Thermo Fisher Scientific, Inc.); Varioskan LUX multifunctional enzyme labeling instrument (Thermo Fisher Scientific, Inc.); and SMART Spectro Spectrophotometer (LaMotte).

Drugs and reagents. The following drugs and reagents were procured for the experiments: Etomidate (Jiangsu Enhua Pharmaceutical Co.); 0.9\% sodium chloride injection (Zhejiang DuBang Pharmaceutical Co.); TRIzol (Takara Bio Inc.); complete protein extraction kit (Beijing Solarbio Science \& Technology Co., Ltd.); anti-Nrf2 protein antibody (Santa Cruz, USA); anti-HO-1 protein antibody (Santa Cruz, USA); anti- $\beta$-actin antibody (Santa Cruz Biotechnology, Inc.); PRIME-SCRIPT RT-PCR kit (Takara Bio Inc.); SYBR PreMix Ex kits (Takara Bio Inc.); tumor necrosis factor- $\alpha$ (TNF- $\alpha$ ), interleukin (IL)-6, IL-1 $\beta$ and IL-10 ELISA kits (Shanghai Westang Biotechnology Co., Ltd.); myeloperoxidase (MPO), superoxide dismutase (SOD), catalase (CAT) and malondialdehyde (MDA) kits (Nanjing Jiancheng Bioengineering Institute); and anti-mouse IgG antibody (Cell Signaling Technology, Inc.).

Grouping of experimental animals and preparation of model. Fifty C57BL/6 mice were randomly divided into five groups (ten mice in each group): Blank control group (CG), model group (MG), high oxygen exposure + low etomidate dose group (ELG, $0.3 \mathrm{mg} \cdot \mathrm{kg}^{-1}$ ), high oxygen exposure + moderate etomidate dose group (EMG, $\left.3.0 \mathrm{mg} \cdot \mathrm{kg}^{-1}\right)$, and high oxygen exposure + high etomidate dose group (EHG, $10 \mathrm{mg} \cdot \mathrm{kg}^{-1}$ ). The CG mice were exposed to room air, whereas mice in the other groups were used as the HALI model. The mice were housed in an airtight Plexiglas chamber, and $100 \%$ oxygen was blown continuously into the chamber at a flow rate of 4.5-5 1/min. The appropriate dose of etomidate was calculated according to the body weight of each mouse. According to a relevant study (18), etomide was mixed with sterile normal saline to prepare a $10 \mathrm{ml} \cdot \mathrm{kg}^{-1}$ solution. The ELG, EMG, and EHG mice were intraperitoneally injected with the corresponding dose of etomidate once a day, whereas the CG and MG mice were injected with normal saline $\left(10 \mathrm{ml} \cdot \mathrm{kg}^{-1}\right)$ once daily for 3 consecutive days. $24 \mathrm{~h}$ after the last injection, the mice were euthanized by intraperitoneal injection of pentobarbital sodium $\left(120 \mathrm{mg} \cdot \mathrm{kg}^{-1}\right.$ i.p.), following which the lung tissues were harvested and the bronchoalveolar lavage fluid (BALF) was collected.

Pulmonary histopathological examination. The upper lobe of the right lung was cut, immersed in $10 \%$ formalin, and embedded in paraffin. Routine hematoxylin-eosin (HE) stained sections $(4-5 \mu \mathrm{m})$ were prepared at room temperature for 120-160 min (the duration was adjusted according to the staining results), and histopathological changes in the lung tissues were observed using light microscopy (magnification, $\mathrm{x} 400$ ) to determine the lung injury score (LIS) (19) using the following criteria: 0 (no changes in the alveolar area), 1 (diffuse inflammatory cell infiltration, predominant neutrophil infiltration, no alveolar wall thickening); 2 (diffuse inflammatory cell, neutrophil and monocyte infiltration, and mild alveolar wall thickening), 3 (2-3-fold increase in alveolar wall thickness), 4 (alveolar wall thickening with 25\% lung consolidation), and 5 (alveolar wall thickening with $>50 \%$ lung consolidation).

Determination of the lung wet-to-dry (W/D) ratio. The degree of pulmonary edema was assessed using the W/D ratio, with the wet weight $(\mathrm{W})$ obtained by weighing the lung tissue immediately after isolation, and the dry weight (D) obtained by weighing the lung tissue after dehydration for $48 \mathrm{~h}$ at $80^{\circ} \mathrm{C}$.

Measurement of MDA, MPO, SOD and CAT levels in lung tissues. Based on the ratio of the weight of the lung tissue (g) and the volume of $0.9 \%$ normal saline $(\mathrm{ml})(=1: 9)$, the lung tissue in the glass homogenizer was manually homogenized to obtain a $10 \%$ homogenate. The homogenate was centrifuged at $4^{\circ} \mathrm{C}$ for $10 \mathrm{~min}$ at $16,000 \mathrm{xg}$, and the supernatant obtained after centrifugation was used as the sample. The MDA levels were measured using thiobarbituric acid colorimetry (Malondialdehyde assay kit, cat. no. A003-1-2), and the absorbance of MDA was measured at $532 \mathrm{~nm}$ wavelength. The activities of MPO, SOD, and CAT were measured using a colorimetric assay, the xanthine oxidase method, and the UV absorption method, respectively. The activities of CAT, SOD, and MPO were measured using Catalase assay kit (cat. no. A007-2-1), SOD assay kit (cat. no. A001-1-2), and MPO assay kit (cat. no. A044-1-1), respectively, and the absorbance values were measured at wavelengths of 405 , 550 and $460 \mathrm{~nm}$, respectively.

Expression of Nrf2 and HO-1 mRNA in lung tissues. Total RNA was extracted from the lung tissues using TRIzol ${ }^{\circledR}$ (Thermo Fisher Scientific, Inc.) according to the instructions of the manufacturer. After the RNA concentration was determined 
Table I. Quantitative analysis of CAT, MDA, SOD and MPO in different groups.

\begin{tabular}{lcccc}
\hline Group & CAT $(\mathrm{U} / \mathrm{mg})$ & MDA $(\mathrm{nmol} / \mathrm{mg})$ & SOD $(\mathrm{U} / \mathrm{mg})$ & $\mathrm{MPO}(\mathrm{U} / \mathrm{g})$ \\
\hline CG & $8.04 \pm 0.41$ & $2.38 \pm 0.29$ & $82.68 \pm 7.67$ & $2.52 \pm 0.37$ \\
MG & $12.91 \pm 0.50^{\mathrm{a}}$ & $7.69 \pm 0.40^{\mathrm{a}}$ & $103.44 \pm 8.01^{\mathrm{a}}$ & $12.13 \pm .045^{\mathrm{a}}$ \\
ELG & $14.87 \pm 0.54^{\mathrm{a}-\mathrm{c}}$ & $4.32 \pm 0.47^{\mathrm{a}-\mathrm{c}}$ & $132.56 \pm 10.91^{\mathrm{a}-\mathrm{c}}$ & $6.48 \pm 0.33^{\mathrm{a}-\mathrm{c}}$ \\
EMG & $17.72 \pm 0.59^{\mathrm{a}-\mathrm{d}}$ & $3.11 \pm 0.30^{\mathrm{a}-\mathrm{c}}$ & $150.83 \pm 11.04^{\mathrm{a}-\mathrm{d}}$ & $5.79 \pm .039^{\mathrm{a}-\mathrm{c}}$ \\
EHG & $10.05 \pm 0.46^{\mathrm{a}}$ & $6.73 \pm 0.42^{\mathrm{a}}$ & $104.25 \pm 9.82^{\mathrm{a}}$ & $11.08 \pm 0.50^{\mathrm{a}}$ \\
\hline
\end{tabular}

Values are mean $\pm \mathrm{SD}$. ${ }^{\mathrm{a}} \mathrm{P}<0.05$ vs. $\mathrm{CG} ;{ }^{\mathrm{b}} \mathrm{P}<0.05$ vs. MG; ${ }^{\mathrm{C}} \mathrm{P}<0.05$ vs. EHG; ${ }^{\mathrm{d}} \mathrm{P}<0.05$ vs. ELG. CAT, catalase; MDA, malondialdehyde; SOD, superoxide dismutase; and MPO, myeloperoxidase; CG, blank control group; MG, model group; ELG, high oxygen exposure + low etomidate dose group (0.3 mg kg-1); EMG, high oxygen exposure + moderate etomidate dose group (3.0 mg kg-1); EHG, high oxygen exposure + high etomidate dose group $\left(10 \mathrm{mg} \cdot \mathrm{kg}^{-1}\right)$.

spectrophotometrically, $1 \mu \mathrm{g}$ RNA was used to synthesize cDNA using the PRIME-SCRIPTRT-PCR kit [at $37^{\circ} \mathrm{C}$ for $15 \mathrm{~min}$ (reverse transcription reaction), 1 cycle; at $85 \mathrm{C}$ for $5 \mathrm{sec}$ (enzyme inactivation reaction), 1 cycle; maintaining at $4^{\circ} \mathrm{C}, 1$ cycle]. Quantitative polymerase chain reaction was performed using the SYBR PreMix Ex kit and an ABI Prism ${ }^{\circledR} 7500$ fluorescent quantitative PCR instrument. Thermocycling conditions: $50^{\circ} \mathrm{C}$ for $2 \mathrm{~min}, 95^{\circ} \mathrm{C}$ for $10 \mathrm{~min}$, then $95^{\circ} \mathrm{C}$ for $15 \mathrm{sec}, 60^{\circ} \mathrm{C}$ for $1 \mathrm{~min}, 40$ cycles. The primer sequences used were as follows: Nrf2 forward, 5'-GTC AGCGACGGAAAGAGTA-3'; Nrf2 reverse, 5'-ACCTGGGAG TAGTTGGCA-3'; HO-1 forward, 5'-CGCAACAAGCAGAAC CCA-3'; HO-1 reverse, 5'-GCGTGCAAGGGATGATTTCC-3'; $\beta$-actin forward, 5'-GGGAAATCGTGCGTGACATCAAAG-3'; and $\beta$-actin reverse, 5'-AACCGCTCGTTGCCAATAGT-3'. The expression of the relevant genes was quantified using the $2^{-\Delta \Delta \mathrm{Cq}}$ method, using $\beta$-actin as the internal reference (20).

Measurement of $\mathrm{Nrf} 2$ and $\mathrm{HO}-1$ protein expression levels in lung tissues. Total protein was extracted from the lung tissue (T-PER Tissue Protein Extraction Reagent; cat. no. 78510; Thermo Fisher Scientific, Inc.), and the Bradford method was used to quantify total protein. Protein samples were separated by electrophoresis in $10 \%$ SDS-PAGE gels $(10 \mu \mathrm{g}$ protein loaded per lane) and transferred to polyvinylidene difluoride membranes. The membranes were blocked by treating with $5 \%$ skimmed milk for $1 \mathrm{~h}$ at room temperature and probed with anti-Nrf2 (1:500; cat. no. Sc365949), anti-HO-1 (1:1,000; cat. no. Sc390991), and anti- $\beta$-actin (1:1,000; cat. no. Sc81178) antibodies, using Helicobacter pylori-coupled anti-mouse IgG $(1: 1,000$; cat. no. $7076 S)$ as the secondary antibody. Images were recorded using a gel imager and analyzed using the AlphaImage software v1.4.0 (GraphPad Software, Inc.).

Detection of inflammatory factors. After the mice were sacrificed, normal saline was injected into the tracheal tube for bronchoalveolar lavage. After repeated lavage, BALF was collected in a centrifuge tube, centrifuged at $110 \mathrm{x} \mathrm{g}$ for $10 \mathrm{~min}$ at $4^{\circ} \mathrm{C}$, and the supernatant was collected and stored at $-70^{\circ} \mathrm{C}$. The concentrations of TNF- $\alpha$, IL-1 $\beta$, IL- 6 and IL-10 in the BALF were determined using ELISA. Absorbance was measured at $450 \mathrm{~nm}$, and the concentrations of TNF- $\alpha$ (cat.no. F26260), IL-1 $\beta$ (cat. no. F85180), IL-6 (cat. no. F10830) and IL-10 (cat. no. F10870) were calculated by drawing a standard curve based on the absorbance value of the standard.
Statistical analysis. Data are expressed as mean \pm SD. One-way analysis of variance (ANOVA) was performed using SPSS software (version 22.0; IBM Corp.), followed by Bonferroni post hoc test. $\mathrm{P}<0.05$ was considered to indicate a statistically significant difference.

\section{Results}

Lung histopathological changes and LIS values. HE staining showed that the CG mice presented with normal lung tissue structure, with no pathological changes (Fig. 1A). Compared with the CG mice, noticeable alveolar hemorrhage, edema, alveolar wall thickening, inflammatory cell infiltration, and hyaline membrane formation were observed in the MG mice after $72 \mathrm{~h}$ (Fig. 1B). Following etomidate administration at low and moderate doses during the continuous inhalation of oxygen at high concentrations, the ELG and EMG mice exhibited mild alveolar pathological changes, intact lung tissue, and fewer inflammatory cells (Fig. 1C and D), whereas the EHG mice, which were administered with etomidate at high doses, showed severe pathological changes, similar to that observed in the MG mice (Fig. 1E).

The MG and EHG mice showed elevated LIS values $(\mathrm{P}<0.05)$ compared with that in the $\mathrm{CG}$ mice. Compared with the MG and EHG mice, the ELG and EMG mice showed lower LIS values $(\mathrm{P}<0.05$; Fig. $1 \mathrm{~F})$.

Low and moderate doses of etomidate decreases the lung W/D ratio in mice with HALI. The MG, ELG and EHG mice exhibited an increased $\mathrm{W} / \mathrm{D}$ ratio $(\mathrm{P}<0.05)$ compared with that of the CG mice. The ELG and EMG mice exhibited a decreased W/D ratio $(\mathrm{P}<0.05)$ compared with that of the $\mathrm{MG}$ and $\mathrm{EHG}$ mice. The EMG mice showed a lower W/D ratio compared with that of the ELG mice $(\mathrm{P}<0.05$; Fig. 2$)$.

Effects of etomidate on the oxidative stress response. The MDA content was higher and the SOD and CAT activities were also enhanced in MG, ELG, EMG and EHG mice compared with that of the CG mice $(\mathrm{P}<0.05)$. The MDA content was lower and the SOD and CAT activities were higher in the ELG and EMG mice compared with that of the MG and EHG mice $(\mathrm{P}<0.05)$. The EMG mice showed higher CAT and SOD activities compared with that of the ELG mice $(\mathrm{P}<0.05$; Fig. 3, Table I). 


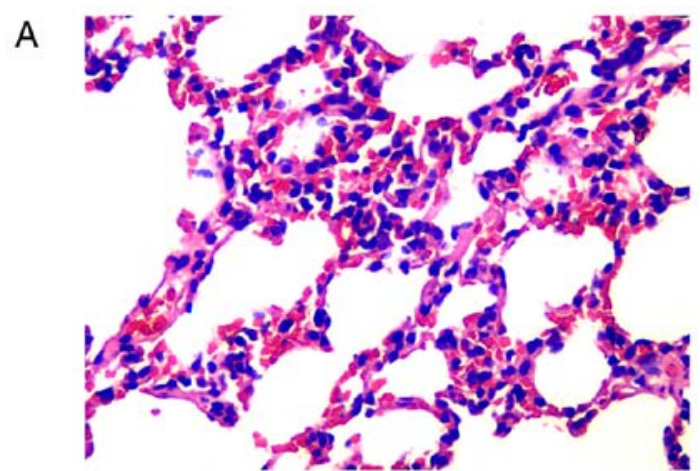

B
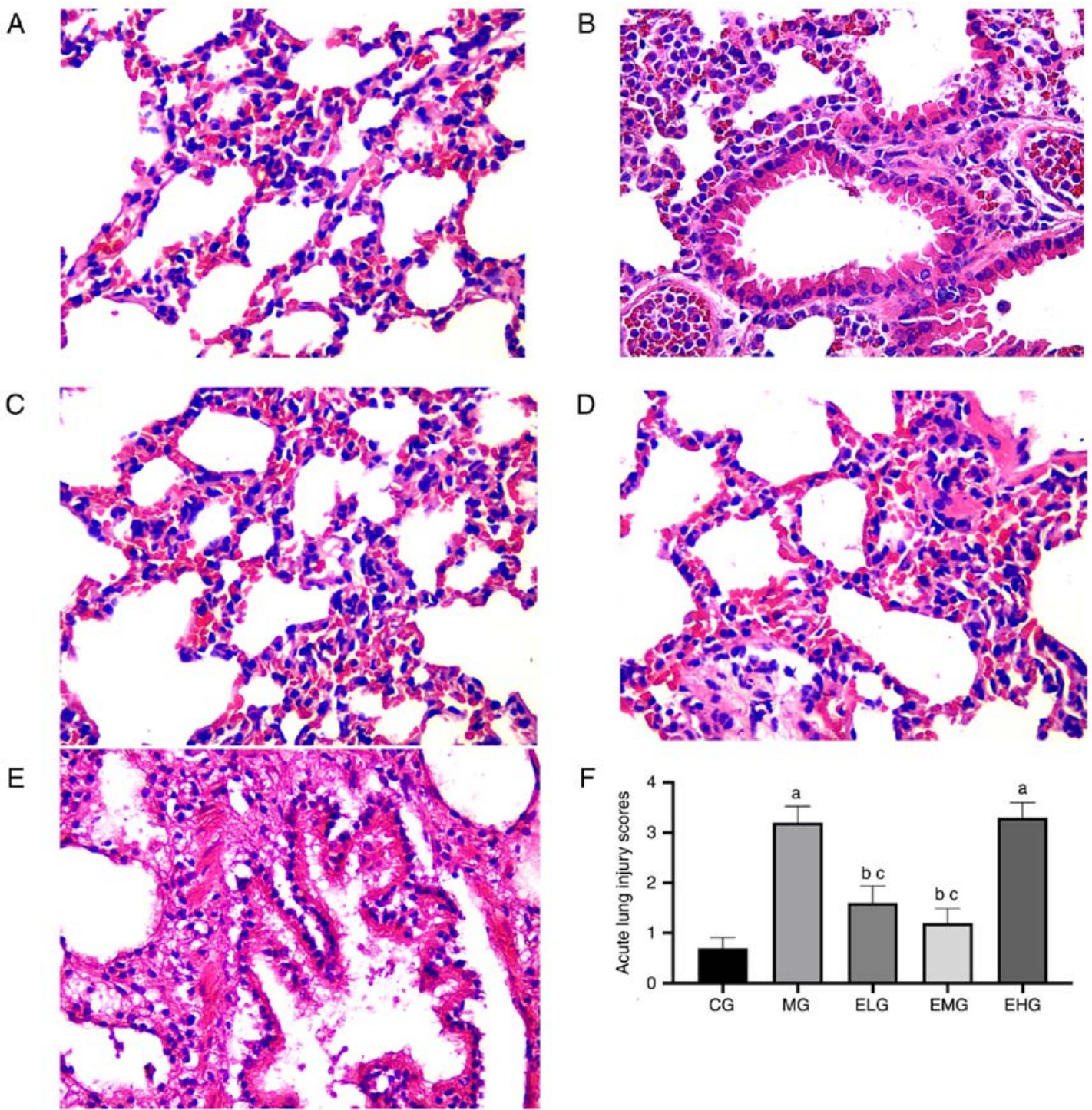

D

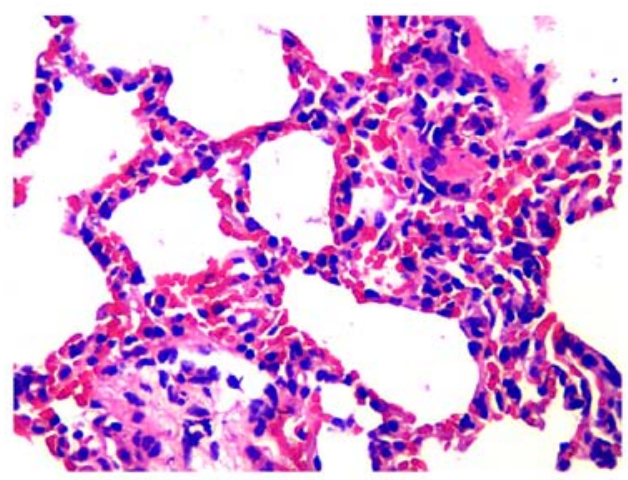

$\mathrm{F}$

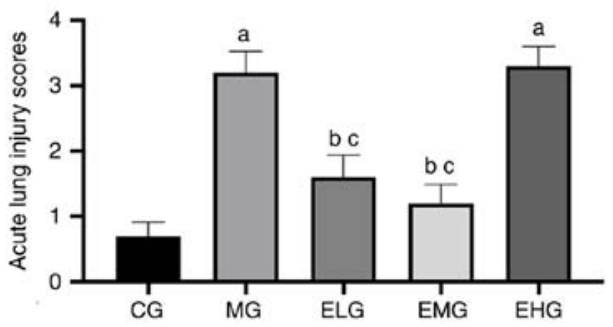

Figure 1. Effects of etomidate on hyperoxia-induced acute lung injury. Hematoxylin and eosin staining of lung sections (magnification, x400) from each group: (A) CG; (B) MG; (C) ELG; (D) EMG; and (E) EHG. Lung injury (F) was scored by observing the morphological structure and expressed as the mean \pm SE. ${ }^{\mathrm{P}} \mathrm{P}<0.05$ vs. CG; ${ }^{\mathrm{b}} \mathrm{P}<0.05 \mathrm{vs}$. MG; ${ }^{\mathrm{c}} \mathrm{P}<0.05$ vs. EHG. CG, blank control group; MG, model group; ELG, high oxygen exposure + low etomidate dose group $\left(0.3 \mathrm{mg} \cdot \mathrm{kg}^{-1}\right)$; EMG, high oxygen exposure + moderate etomidate dose group ( $\left.3.0 \mathrm{mg} \cdot \mathrm{kg}^{-1}\right)$; EHG, high oxygen exposure + high etomidate dose group $\left(10 \mathrm{mg} \cdot \mathrm{kg}^{-1}\right)$.

Low and moderate etomidate doses upregulates Nrf2 and HO-1 mRNA levels. The mRNA expression levels of Nrf2 and HO-1 were elevated $(\mathrm{P}<0.05)$ in MG, ELG, EMG and EHG mice compared with that of the CG mice. The mRNA expression levels of Nrf2 and HO-1 were elevated $(\mathrm{P}<0.05)$ in the ELG and EMG mice compared with that of the MG and EHG mice. The mRNA expression of Nrf2 and HO- 1 was elevated in the EMG mice compared with that of the ELG mice $(\mathrm{P}<0.05$; Fig. 4D and E; Table II).

Etomidate at low to moderate doses increases $\mathrm{Nrf} 2$ and $\mathrm{HO}-1$ protein levels. Western blotting results revealed that the protein expression levels of Nrf2 and HO-1 were elevated $(\mathrm{P}<0.05)$ in MG, ELG, EMG and EHG mice compared with that of CG mice. Furthermore, the protein expression levels of Nrf2 and HO-1 were significantly elevated in ELG and EMG mice, with the levels in EMG mice comparable to those of the MG and ELG mice, respectively ( $\mathrm{P}<0.05$; Fig. 4A-C).
Effects of etomidate on the inflammatory response. The levels of TNF- $\alpha$, IL-6, IL- $1 \beta$, IL-10 and MPO were higher in the MG, ELG, EMG and EHG mice compared with that of the CG mice $(\mathrm{P}<0.05)$. TNF- $\alpha$, IL-6, IL-1 $\beta$ and MPO levels were lower in the ELG and EMG mice, and the levels of the anti-inflammatory factor IL-10 were lower in MG and EHG mice compared with that of the ELG and EMG mice $(\mathrm{P}<0.05)$. Compared with the ELG mice, the EMG mice showed lower TNF- $\alpha$, IL- 6 , and IL-1 $\beta$ levels and higher IL-10 levels $(\mathrm{P}<0.05$; Fig. 5).

\section{Discussion}

Among the clinical anesthetics available, etomidate is frequently administered to critically ill patients owing to its reliable sedative efficacy and stable hemodynamic effects. Besides, etomidate seems to exert organo-protective effects by decreasing oxidative stress. A study has shown that etomidate alleviated rabbit spinal cord ischemia-reperfusion injury 
Table II. Relative expression levels of Nrf2 and HO-1 mRNA in different groups.

\begin{tabular}{lll}
\hline Group & \multicolumn{1}{c}{ Nrf2 } & \multicolumn{1}{c}{ HO- 1} \\
\hline CG & $0.823 \pm 0.016$ & $2.621 \pm 0.040$ \\
MG & $1.707 \pm 0.029^{\mathrm{a}}$ & $4.086 \pm 0.031^{\mathrm{a}}$ \\
ELG & $3.375 \pm 0.039^{\mathrm{a}-\mathrm{c}}$ & $5.472 \pm 0.042^{\mathrm{a}-\mathrm{c}}$ \\
EMG & $5.436 \pm 0.052^{\mathrm{a}-\mathrm{d}}$ & $7.391 \pm 0.056^{\mathrm{a}-\mathrm{d}}$ \\
EHG & $1.612 \pm 0.044^{\mathrm{a}}$ & $4.003 \pm 0.039^{\mathrm{a}}$ \\
\hline
\end{tabular}

Values are mean $\pm \mathrm{SD}$. ${ }^{\mathrm{a}} \mathrm{P}<0.05$ vs. $\mathrm{CG}$; ${ }^{\mathrm{b}} \mathrm{P}<0.05$ vs. $\mathrm{MG}$; ${ }^{\mathrm{c}} \mathrm{P}<0.05$ vs. EHG; ${ }^{\mathrm{d}} \mathrm{P}<0.05$ vs. ELG. HO-1, heme oxygenase-1; Nrf2, nuclear factor-erythroid 2-p45-related factor 2; CG, blank control group; MG, model group; ELG, high oxygen exposure + low etomidate dose group $\left(0.3 \mathrm{mg} \cdot \mathrm{kg}^{-1}\right) ; \mathrm{EMG}$, high oxygen exposure + moderate etomidate dose group $\left(3.0 \mathrm{mg} \cdot \mathrm{kg}^{-1}\right)$; EHG, high oxygen exposure + high etomidate dose group $\left(10 \mathrm{mg} \cdot \mathrm{kg}^{-1}\right)$.

caused by aortic occlusion by decreasing oxidative stress (21). Zhao et al (9) found that etomidate can protect retinal ganglion cells in adult rats by activating the antioxidative stress response, significantly decreasing the levels of nitric oxide and MDA in the retina, and increasing the level of glutathione (GSH). Another study showed that etomidate can alleviate the inflammatory response and oxidative stress in rats with myocardial ischemia-reperfusion injury, characterized by the increase in SOD and GSH levels and the decrease in MDA levels in myocardial tissue, as well as the decrease in iNOS levels and increase in IL-10 levels in serum and myocardial tissue (7). In clinical studies, the application of etomidate to maintain sedation during lower limb fracture surgery helped effectively maintain the serum SOD activity after the fracture was complicated with ischemia-reperfusion injury, inhibited the release of inflammatory factors, and decreased the incidence of postoperative complications caused by anesthesia (6). In the present study, a HALI mouse model was established, and etomidate was administered at different concentrations $\left(0.3,3\right.$ and $\left.10 \mathrm{mg} \cdot \mathrm{kg}^{-1}\right)$ to investigate the potential lung-protective effects. Since the unit body surface area of mice is approximately nine times that of humans, the usual clinical induction dose of etomidate $\left(0.3 \mathrm{mg} \cdot \mathrm{kg}^{-1}\right)$ was converted to $2.7 \mathrm{mg} \cdot \mathrm{kg}^{-1}$ for mice. As indicated in available literature, etomidate is administered to mice at doses ranging from 0.3 to $30 \mathrm{mg} \cdot \mathrm{kg}^{-1}$ (22-24). Studies have shown that the sleep duration in mice injected with etomidate is dose-dependent but can last for 6-10 min at $0.3 \mathrm{mg} \cdot \mathrm{kg}^{-1}$, and recovery is rapid and complete without any signs of hangover (25). Therefore, $0.3 \mathrm{mg} \cdot \mathrm{kg}^{-1}$ was selected as the minimum dose. In some studies, etomidate at a maximum dose of $10 \mathrm{mg} \cdot \mathrm{kg}^{-1}$ occasionally caused death in mice (26). Therefore, it was decided to use 0.3 , 3 and $10 \mathrm{mg} \cdot \mathrm{kg}^{-1}$ of etomidate as the low, moderate, and high doses based on evidences from a relevant study (22). In addition, in order to avoid the impact of different liquid volume on lung tissue and according to a previous study (18), the same drug administration volume of $10 \mathrm{ml} / \mathrm{kg}^{-1}$ was adopted. The results showed that 0.3 and $3 \mathrm{mg} \cdot \mathrm{kg}^{-1}$ etomidate attenuated the pathological changes caused by HALI, inhibited the activation of pro-inflammatory factors, increased the levels of

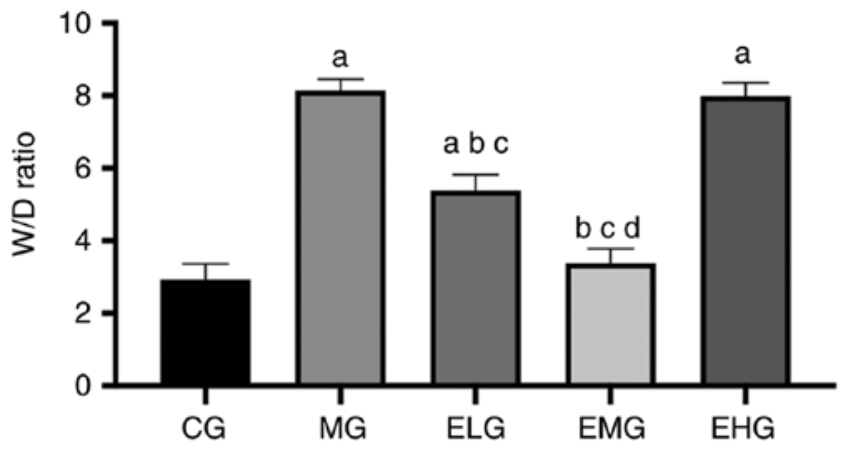

Figure 2. Effects of etomidate on the lung W/D weight ratio in mice with hyperoxia-induced acute lung injury. Pulmonary W/D weight ratio: $\mathrm{W} / \mathrm{D}=[$ wet weight/dry weight] $\times 100 \%$, expressed as the mean \pm SD. ${ }^{a} \mathrm{P}<0.05$ vs. CG; ${ }^{\mathrm{b}} \mathrm{P}<0.05$ vs. $\mathrm{MG} ;{ }^{\mathrm{c}} \mathrm{P}<0.05$ vs. EHG; ${ }^{\mathrm{d}} \mathrm{P}<0.05$ vs. ELG. W/D, wet/dry; CG blank control group; MG, model group; ELG, high oxygen exposure + low etomidate dose group $\left(0.3 \mathrm{mg} \cdot \mathrm{kg}^{-1}\right)$; EMG, high oxygen exposure + moderate etomidate dose group $\left(3.0 \mathrm{mg} \cdot \mathrm{kg}^{-1}\right)$; EHG, high oxygen exposure + high etomidate dose group $\left(10 \mathrm{mg} \cdot \mathrm{kg}^{-1}\right)$.

anti-inflammatory factors, inhibited lipid peroxidation of lung tissue, and enhanced the activities of antioxidant enzymes. Notably, $3 \mathrm{mg} \cdot \mathrm{kg}^{-1}$ etomidate exerted a stronger protective effect. Additionally, etomidate upregulated the expression of Nrf2/HO-1 mRNA and promoted the synthesis and secretion of Nrf2/HO-1 proteins. However, at the high dose $\left(10 \mathrm{mg} \cdot \mathrm{kg}^{-1}\right)$, etomidate failed to attenuate lung tissue injury. It is speculated that etomidate inhibits hyperoxia-induced inflammation and oxidative stress in a dose-dependent manner in HALI, which may be associated with the upregulation of the Nrf2/HO-1 pathway. These findings support the rational clinical use of etomidate.

Notably, the inflammatory cascade and oxidative stress play central roles in the development of HALI (27). In mice, the prolonged inhalation of oxygen at high concentrations leads to the large-scale recruitment of inflammatory cells in the lungs, particularly the recruitment and activation of neutrophils, promoting the release of inflammatory factors and oxidative stress mediators (28-30), which is a marker of neutrophil infiltration and activation in tissues. While the monocyte-macrophage system releases various pro-inflammatory factors in vivo, monocytes and B cells also release IL-10 to inhibit the expression of multiple pro-inflammatory cytokines, chemokines, and chemokine receptors, and suppress the inflammatory response (31). In the present study, mice that continuously inhaled oxygen at high concentrations for $72 \mathrm{~h}$ showed elevated levels of TNF- $\alpha$, IL- 6 and IL- $1 \beta$ in the BALF, as well as increased MPO levels in lung tissues. Although there is no clear clinical method to treat HALI, some basic studies have pointed out that dexmedetomidine, exogenous IL-10 and activated protein $\mathrm{C}$ can all decrease HALI (32-35). However, the new findings indicate that at low and moderate doses, etomidate decreased the infiltration of neutrophils, lowered the levels of MPO as well as pro-inflammatory factors, and promoted the release of IL-10, thereby reversing the imbalance in the inflammatory state and promoting the recovery of lung injury.

Reportedly, the alveolar epithelium, basement membrane and capillary endothelial cells are destroyed in the inflammatory state, which leads to the loss of alveolar-capillary barrier 

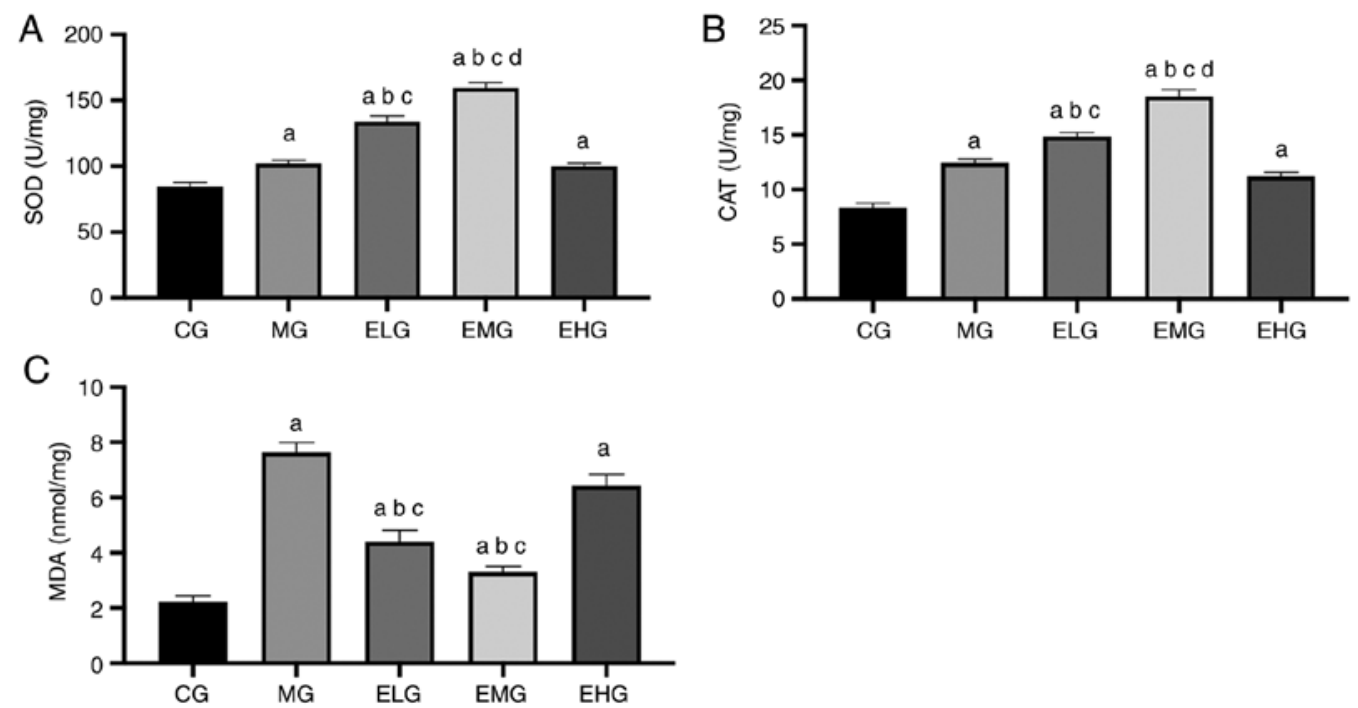

Figure 3. Effects of etomidate on antioxidant enzymes and oxidation products in mouse lung tissue. (A) SOD; (B) CAT; and (C) MDA, expressed as the mean \pm SE. ${ }^{a} \mathrm{P}<0.05$ vs. $\mathrm{CG}$; ${ }^{\mathrm{P}} \mathrm{P}<0.05$ vs. $\mathrm{MG}$; ${ }^{\mathrm{C}} \mathrm{P}<0.05$ vs. EHG; ${ }^{\mathrm{d}} \mathrm{P}<0.05$ vs. ELG. SOD, superoxide dismutase; CAT, catalase; MDA, malondialdehyde; $\mathrm{CG}$, blank control group; MG, model group; ELG, high oxygen exposure + low etomidate dose group $\left(0.3 \mathrm{mg} \cdot \mathrm{kg}^{-1}\right)$; EMG, high oxygen exposure + moderate etomidate dose group $\left(3.0 \mathrm{mg} \cdot \mathrm{kg}^{-1}\right)$; EHG, high oxygen exposure + high etomidate dose group $\left(10 \mathrm{mg} \cdot \mathrm{kg}^{-1}\right)$.

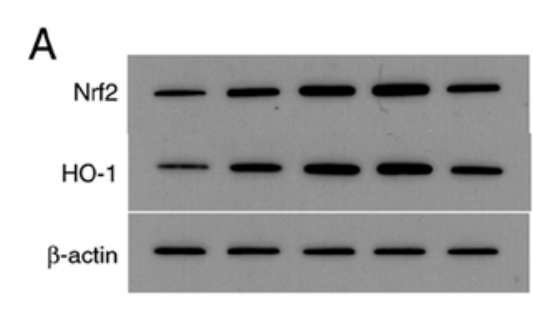

B

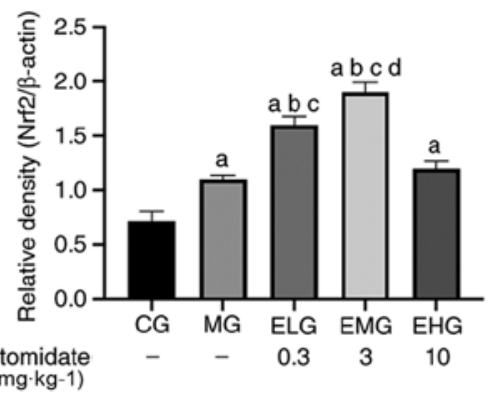

E

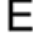

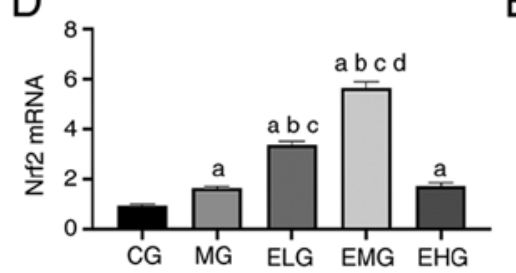

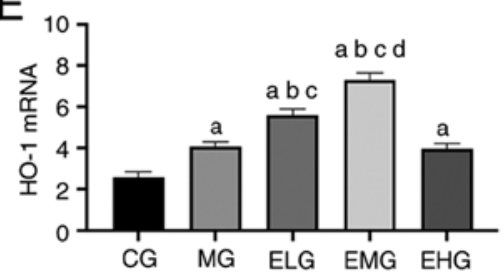

Figure 4. Effects of etomidate on the HO-1/Nrf2 pulmonary pathway. (A) HO-1 mRNA expression; (B) Nrf2 mRNA expression; (C) western blot analysis results of (D) Nrf2 and (E) HO-1, expressed as the mean $\pm \mathrm{SD}$. ${ }^{\mathrm{P}}<0.05$ vs. CG; ${ }^{\mathrm{b}} \mathrm{P}<0.05$ vs. MG; ${ }^{\mathrm{C}} \mathrm{P}<0.05$ vs. EHG; ${ }^{\mathrm{d}} \mathrm{P}<0.05$ vs. ELG. HO-1, heme oxygenase-1; Nrf2, nuclear factor-erythroid 2-p45-related factor 2; CG, blank control group; MG, model group; ELG, high oxygen exposure + low etomidate dose group $\left(0.3 \mathrm{mg} \cdot \mathrm{kg}^{-1}\right) ; \mathrm{EMG}$, high oxygen exposure + moderate etomidate dose group $\left(3.0 \mathrm{mg} \cdot \mathrm{kg}^{-1}\right) ; \mathrm{EHG}$, high oxygen exposure + high etomidate dose group $\left(10 \mathrm{mg} \cdot \mathrm{kg}^{-1}\right)$.

integrity, increases the permeability of alveolar capillaries and alveolar epithelial cells, and promotes the influx of macromolecules such as albumin into the alveolar space, which consequently leads to pulmonary edema, hyaline membrane formation and alveolar wall thickening (36). Furthermore, ROS generated by activated neutrophils and monocytes during inflammation has been shown to affect biofilm stability (37). Pulmonary edema is positively associated with the inflammatory status. In the present study, the degree of lung edema was evaluated by measuring the W/D ratio, whereas the severity of lung histopathological changes was quantified based on the LIS value. In HALI mice, the lung tissue sections showed severe pathological changes, such as inflammatory cell infiltration, alveolar congestion, and alveolar wall thickening.
Compared with that of the CG mice, the lung W/D ratio was higher in both MG and EHG mice, which was consistent with the trend observed for the LIS values. Conversely, at low and moderate doses, etomidate effectively suppressed morphological damage to lung tissues and decreased pulmonary edema, inflammatory infiltrates and lung injury in mice. It was speculated that etomidate may decelerate the process of lung injury by inhibiting the infiltration of inflammatory cells into lung tissues and stabilizing the permeability of the lung epithelial cell membrane and microvascular membrane.

Oxidative stress also plays a critical role in ALI pathology. ROS is a by-product of aerobic metabolism, and a hyperoxic environment can induce ROS production (38). It should be noted that there is no clear answer to the limit of oxygen 

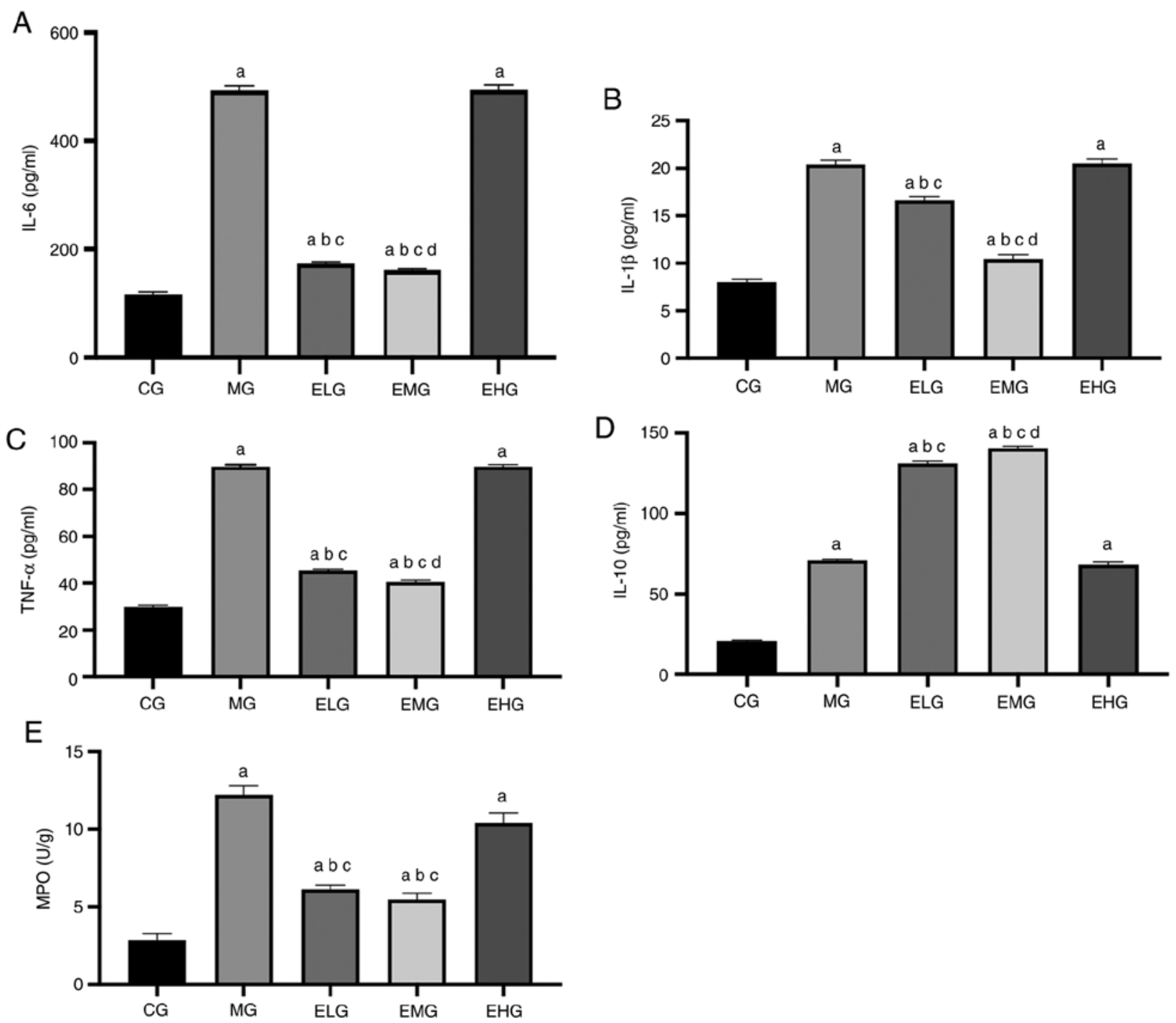

Figure 5. Effects of etomidate on the levels of pro-inflammatory and anti-inflammatory factors and MPO in the bronchoalveolar lavage fluid of hyperoxia-induced acute lung injury mice. (A) IL-6; (B) IL-1 $\beta$; (C) TNF- $\alpha$; (D) IL-10; (E) MPO, expressed as the mean \pm SD. ${ }^{a} \mathrm{P}<0.05$ vs. CG; ${ }^{\text {b }}<0.05$ vs. MG; ${ }^{\mathrm{c}} \mathrm{P}<0.05$ vs. EHG; ${ }^{\mathrm{P}}<0.05$ vs. ELG. MPO, myeloperoxidase; IL-, interleukin-; TNF, tumor necrosis factor; CG, blank control group; MG, model group; ELG, high oxygen exposure + low etomidate dose group $\left(0.3 \mathrm{mg} \cdot \mathrm{kg}^{-1}\right) ; \mathrm{EMG}$, high oxygen exposure + moderate etomidate dose group $\left(3.0 \mathrm{mg} \cdot \mathrm{kg}^{-1}\right) ; \mathrm{EHG}$, high oxygen exposure + high etomidate dose group $\left(10 \mathrm{mg} \cdot \mathrm{kg}^{-1}\right)$.

concentration and duration of lung damage. At present, it is clinically believed that when the inhaled oxygen concentration is $>60 \%$, most of the nitrogen in the alveoli is replaced by oxygen, and the oxygen in the alveoli quickly diffuses into the blood. If the air in the corresponding alveoli is not replenished in time due to poor respiratory tract or other reasons, collapse may occur, causing atelectasis, and the dose-dependent manner increases the patient's 7-day postoperative respiratory complications and 30-day mortality (39). Notably, exogenous and endogenous ROS-mediated oxidative stress is a key factor in initiating the expression of inflammatory mediators and inducing cellular damage (40). Under hyperoxic conditions, the major sites of ROS production are the mitochondria and nicotinamide adenine dinucleotide oxidase (41). A significant increase in ROS levels can trigger an oxidative stress response that eventually causes oxidative damage to cellular macromolecules such as DNA, lipids, and proteins, leading to DNA double-strand breaks, chromosomal alterations, and other functional changes (42). The resulting state of oxidative/hyperoxic stress consequently activates the inflammatory response in lung tissues $(43,44)$. The infiltration of neutrophils and monocytes into the pulmonary circulation and lung interstitium can further increase the levels of ROS in the lung, thereby aggravating cell injury $(45,46)$. In addition, ROS can also react with various unsaturated fatty acids and cholesterol on the cell membrane, leading to oxidative damage and apoptosis (47). As a metabolite of ROS, the MDA levels reflect the extent of lipid peroxidation, protein denaturation and impaired endothelial integrity $(48,49)$. ROS elimination is primarily achieved through multiple antioxidant enzymes, including SOD and CAT, which are important endogenous antioxidant enzymes that maintain the dynamic balance between oxidation-reduction reactions (50). In order to assess the status of oxidative stress in lung tissues, the levels of MDA and antioxidant enzymes were measured in lung tissues. The HALI model showed increased MDA and MPO levels. The ELG and EMG mice showed decreased MDA levels and enhanced SOD and CAT activities compared with that of 
the MG mice. This suggests that at low and moderate doses, etomidate can inhibit lipid peroxidation in the lung tissue of HALI mice and significantly promote the activities of antioxidant enzymes, thereby decreasing lung injury. It is believed that the therapeutic effect of etomidate on hyperoxia-induced lung injury can be partly attributed to the maintenance of the oxidative and antioxidative stress balance.

$\mathrm{Nrf} 2$ is the primary regulator of the antioxidative response against hyperoxia-induced oxidative stress. Nrf2 stimulates the expression of multiple genes, most of which encode antioxidant/detoxification enzymes (51), thereby regulating immune stress and antioxidative and anti-inflammatory responses under pathological conditions $(52,53)$. The protective effect of Nrf2 on lung injury induced by oxidative stress was confirmed in adult Nrf2-knockout mice (12,54-56) Under physiological conditions, Nrf2 exists in the cytoplasm as an inactive complex of Kelch-like ECH-associated protein 1 (KEAP-1). Under oxidative stress, Nrf2 is released from KEAP-1 and translocates to the nucleus, following which it binds to specific antioxidant response elements and initiates the transcription of genes encoding proteins with cytoprotective properties, of which HO-1 is the most prominent (57).

HO-1 is a cytoprotective enzyme with important physiological roles in the anti-inflammatory response, antioxidation, cell proliferation and angiogenesis regulation, and can be induced by different stimuli associated with inflammation and oxidative stress, including ROS, heme, cytokines, endotoxins and heavy metals $(58,59)$. Previous studies have shown that the inhibition of HO-1 activity enhances the inflammatory response, whereas the induction of HO-1 enzyme activity effectively suppresses the production of inflammatory mediators $(60,61)$. It was observed that the levels of proteins associated with the Nrf2/HO-1 pathway were mildly elevated in the lung tissue of the HALI model, which was attributed to the activation of the $\mathrm{Nrf} / \mathrm{HO}-1$ pathway in response to hyperoxic stimulation; during lung injury, the production and utilization of Nrf2 and HO-1 are balanced, with seemingly unchanged Nrf2 and HO-1 levels, which may be attributed to self-protective mechanisms. However, this is insufficient to prevent ALI development. Furthermore, following the administration of etomidate at different doses, a significant increase in Nrf2 and HO-1 mRNA expression was observed in the ELG and EMG mice compared with that of the CG mice. The aforementioned finding, combined with the western blotting results, suggested that etomidate may activate the Nrf2/HO-1 pathway, upregulate Nrf2/HO-1 gene expression and promote $\mathrm{Nrf} 2 / \mathrm{HO}-1$ protein synthesis and secretion. Studies have shown that the activation of the $\mathrm{Nrf} 2 / \mathrm{HO}-1$ pathway can effectively suppress inflammatory responses by inhibiting the expression of pro-inflammatory mediators $(13,14)$. Activation of the Nrf2/HO-1 pathway exerts a protective effect on the integrity of alveolar epithelial cells and microvascular membranes, preventing the infiltration of inflammatory cells. Therefore, the activation of the Nrf2/HO-1 pathway plays an important role in the protective effects exerted by etomidate.

Based on the findings of the present study, etomidate appears to exert an organo-protective effect, particularly a lung-protective effect, in addition to its anesthetic effect. Anesthesia remains a rather unexplored subject thus far, and there is no clear and systematic conclusion on the mechanism of action of general anesthetics. In addition to anesthetic effects, there have been several breakthroughs in the alternative properties of general anesthetics, such as organ protection, anti-neuropsychiatric effects and antitumor effects. Similarly, even etomidate, which has been used in clinical practice for several years now, is still being assessed for its potential organo-protective effects beyond its anesthetic effects. In fact, several scholars have explored the additional effects of anesthesia; for example, propofol has been found to prevent cerebral ischemia-reperfusion injury (62), dexmedetomidine has been shown to alleviate spinal cord injury (63), and sevoflurane has been shown to exert anti-inflammatory effects and decrease lung injury in patients (64). In the present study, the alternative uses of etomidate in addition to its anesthetic effect was investigated, and both the point of initiation and preliminary findings of the present study were significant.; this may be one of the organo-protective effects of etomidate.

However, the present study has the following limitations. Firstly, in principle, the recognized drug that is most effective and safest for the treatment of HALI should be selected as the positive control. Unfortunately, there is no definite, effective and clinically recognized drug for the treatment of HALI at present, so the present study is consistent with other associated studies $(65,66)$ without using a positive control. However, a positive control should be selected as a reference for further studies in the future. Secondly, the present findings revealed that the reversal of lung injury induced by etomidate administration at low and moderate doses $\left(0.3\right.$ and $\left.3 \mathrm{mg} \cdot \mathrm{kg}^{-1}\right)$ was not observed upon administration at a high dose $\left(10 \mathrm{mg} \cdot \mathrm{kg}^{-1}\right)$. Thus, etomidate may only exert lung-protective effects within a certain dose range. Further exploration of the optimal etomidate dose required for lung-protective effects is intended in the future.

In summary, the present study showed that etomidate can effectively decrease lung injury in a HALI model within a specific dose range, which may involve the inhibition of inflammatory responses and improvement in antioxidant capacity, and the potential mechanism may involve the upregulation of the Nrf2/HO-1 pathway.

\section{Acknowledgements}

Not applicable.

\section{Funding}

No funding was received.

\section{Availability of data and materials}

The data that support the findings of this study are available from Shanxi Provincial People's Hospital, Taiyuan, Shanxi, China but restrictions apply to the availability of these data, which were used under license for the current study, and so are not publicly available. Data are however available from the authors upon reasonable request and with permission of Shanxi Provincial People's Hospital, Taiyuan, Shanxi, China.

\section{Authors' contributions}

LJ and HH confirm the authenticity of all the raw data; LJ and $\mathrm{HH}$ designed experiments; $\mathrm{HH}, \mathrm{CW}$ and $\mathrm{JW}$ carried out 
experiments and analyzed the data. LJ wrote the manuscript, $\mathrm{LJ}$ and $\mathrm{HH}$ revised the manuscript. All authors approved the final manuscript.

\section{Ethics approval and consent to participate}

The experimental protocol was approved by the Laboratory Animal Ethics Committee of Shanxi Provincial People's Hospital (approval no. 2019-001-05) and is in accordance with the 'Guide for the Care and Use of Laboratory Animals' published by the National Institutes of Health.

\section{Patient consent for publication}

Not applicable.

\section{Competing interests}

The authors declare that they have no competing interests.

\section{References}

1. Nyp MF, Mabry SM, Navarro A, Menden H, Perez RE Sampath V and Ekekezie II: Lung epithelial-specific TRIP-1 overexpression maintains epithelial integrity during hyperoxia exposure. Physiol Rep 6: e13585, 2018.

2. Hovaguimian $\mathrm{F}$, Lysakowski $\mathrm{C}$, Elia $\mathrm{N}$ and Tramèr MR: Effect of intraoperative high inspired oxygen fraction on surgical site infection, postoperative nausea and vomiting, and pulmonary function: Systematic review and meta-analysis of randomized controlled trials. Anesthesiology 119: 303-316, 2013.

3. Allegranzi B, Zayed B, Bischoff P, Kubilay NZ, de Jonge S, de Vries F, Gomes SM, Gans S, WallertED, Wu X, et al: New WHO recommendations on intraoperative and postoperative measures for surgical site infection prevention: An evidence-based global perspective. Lancet Infect Dis 16: e288-e303, 2016.

4. Edmark L, Kostova-Aherdan K, Enlund M and Hedenstierna G: Optimal oxygen concentration during induction of general anesthesia. Anesthesiology 98: 28-33, 2003.

5. Ladha K, Vidal Melo MF, McLean DJ, Wanderer JP, Grabitz SD Kurth $\mathrm{T}$ and Eikermann M: Intraoperative protective mechanical ventilation and risk of postoperative respiratory complications: Hospital based registry study. BMJ 351: h3646, 2015.

6. Li R, Fan L, Ma F, Cao Y, Gao J, Liu H and Li Y: Effect of etomidate on the oxidative stress response and levels of inflammatory factors from ischemia-reperfusion injury after tibial fracture surgery. Exp Ther Med 13: 971-975, 2017

7. Xie D, Li M, Yu K, Lu H and Chen Y: Etomidate alleviates cardiac dysfunction, fibrosis and oxidative stress in rats with myocardial ischemic reperfusion injury. Ann Transl Med 8: $1181,2020$.

8. Djuric M, Kostic S, Nikolic Turnic T, Stankovic S, Skrbic R, Djuric DM, Zivkovic V, Jakovljevic V and Stevanovic P: The comparison of the effects of ketamine and etomidate on cardiodynamics, biochemical and oxidative stress parameters in Wistar male rats. Mol Cell Biochem 474: 125-134, 2020.

9. Zhao X, Kuang F, You YY, Wu MM and You SW: Etomidate affects the anti-oxidant pathway to protect retinal ganglion cells after optic nerve transection. Neural Regen Res 14: 2020-2024 2019.

10. Ates O, Yucel N, Cayli SR, Altinoz E, Yologlu S, Kocak A, Cakir CO and Turkoz Y: Neuroprotective effect of etomidate in the central nervous system of streptozotocin-induced diabetic rats. Neurochem Res 31: 777-783, 2006

11. Cayli SR, Ates O, Karadag N, Altinoz E, Yucel N, Yologlu S, Kocak A and Cakir CO: Neuroprotective effect of etomidate on functional recovery in experimental spinal cord injury. Int J Dev Neurosci 24: 233-239, 2006.

12. Cho HY, Jedlicka AE, Reddy SP, Kensler TW, Yamamoto M, Zhang LY and Kleeberger SR: Role of NRF2 in protection against hyperoxic lung injury in mice. Am J Respir Cell Mol Biol 26: 175-182, 2002 .
13. Loboda A, Damulewicz M, Pyza E, Jozkowicz A and Dulak J: Role of Nrf2/HO-1 system in development, oxidative stress response and diseases: An evolutionarily conserved mechanism. Cell Mol Life Sci 73: 3221-3247, 2016.

14. Chen Z, Zhong H, Wei J, Lin S, Zong Z, Gong F, Huang X, Sun J, $\mathrm{Li} \mathrm{P}$, Lin $\mathrm{H}$, et al: Inhibition of $\mathrm{Nrf} 2 / \mathrm{HO}-1$ signaling leads to increased activation of the NLRP3 inflammasome in osteoarthritis. Arthritis Res Ther 21: 300, 2019.

15. Abraham NG and Kappas A: Pharmacological and clinical aspects of heme oxygenase. Pharmacol Rev 60: 79-127, 2008.

16. Ohta S: Molecular hydrogen as a preventive and therapeutic medical gas: Initiation, development and potential of hydrogen medicine. Pharmacol Ther 144: 1-11, 2014.

17. National Research Council (US): Committee for the Update of the Guide for the Care and Use of Laboratory Animals. Guide for the Care and Use of Laboratory Animals. 8th edition. National Academies Press,Washington, DC, 2011.

18. Paris A, Hein L, Brede M, Brand PA, Scholz J and Tonner PH: The anesthetic effects of etomidate: Species-specific interaction with alpha 2-adrenoceptors. Anesth Analg 105: 1644-1649, 2007.

19. Patel V, Dial K, Wu J, Gauthier AG, Wu W, Lin M, Espey MG, Thomas DD, Ashby CR Jr and Mantell LL: Dietary antioxidants significantly attenuate hyperoxia-induced acute inflammatory lung injury by enhancing macrophage function via reducing the accumulation of airway HMGB1. Int J Mol Sci 21: 977, 2020.

20. Navidshad B, Liang JB and Jahromi MF: Correlation coefficients between different methods of expressing bacterial quantification using real time PCR. Int J Mol Sci 13: 2119-2132, 2012.

21. Yu Q, Zhou Q, Huang H, Wang Y, Tian S and Duan D: Protective effect of etomidate on spinal cord ischemia-reperfusion injury induced by aortic occlusion in rabbits. Ann Vasc Surg 24: 225-232, 2010.

22. Nyman Y, Fredriksson A, Lönnqvist PA and Viberg H: Etomidate exposure in early infant mice (P10) does not induce apoptosis or affect behaviour. Acta Anaesthesiol Scand 60: 588-596, 2016

23. Besnier E, Clavier T, Tonon MC, Selim J, Lefevre-Scelles A, Morin F, Tamion F, Dureuil B, Castel H and Compere V: Ketamine and etomidate down-regulate the hypothalamic-pituitary-adrenal axis in an endotoxemic mouse model. Anesthesiology 127: 347-354, 2017.

24. Benkwitz C, Liao M, Laster MJ, Sonner JM, Eger EI II and Pearce RA: Determination of the EC50 amnesic concentration of etomidate and its diffusion profile in brain tissue: Implications for in vitro studies. Anesthesiology 106: 114-123, 2007.

25. Green CJ, Knight J, Precious S and Simpkin S: Metomidate, etomidate and fentanyl as injectable anaesthetic agents in mice. Lab Anim 15: 171-175, 1981.

26. Liao M, Sonner JM, Husain SS, Miller KW, Jurd R, Rudolph U and Eger EI II: R (+) etomidate and the photoactivable R (+) azietomidate have comparable anesthetic activity in wild-type mice and comparably decreased activity in mice with a N265M point mutation in the gamma-aminobutyric acid receptor beta 3 subunit. Anesth Analg 101: 131-135, table of contents, 2005.

27. Kallet RH and Matthay MA: Hyperoxic acute lung injury. Respir Care 58: 123-141, 2013.

28. Yuan CB, Tian L, Yang B and Zhou HY: Isoalantolactone protects LPS-induced acute lung injury through Nrf2 activation. Microb Pathog 123: 213-218, 2018.

29. Rankin SM: The bone marrow: A site of neutrophil clearance. J Leukoc Biol 88: 241-251, 2010.

30. Ho YC, Lee SS, Yang ML, Huang-Liu R, Lee CY, Li YC and Kuan YH: Zerumbone reduced the inflammatory response of acute lung injury in endotoxin-treated mice via Akt-NFкB pathway. Chem Biol Interact 271: 9-14, 2017. Cannizzaro V, Hantos Z, Sly PD and Zosky GR: Linking lung function and inflammatory responses in ventilator-induced lung injury. Am J Physiol Lung Cell Mol Physiol 300: L112-120, 2011.

31. Zhang Q, Wu D, Yang Y, Liu T and Liu H: Dexmedetomidine alleviates hyperoxia-induced acute lung injury via inhibiting NLRP3 inflammasome activation. Cell Physiol Biochem 42: 1907-1919, 2017

32. Li HD, Zhang QX, Mao Z, Xu XJ, Li NY and Zhang H: Exogenous interleukin-10 attenuates hyperoxia-induced acute lung injury in mice. Exp Physiol 100: 331-340, 2015.

33. Li HD, Zhang ZR, Zhang QX, Qin ZC, He DM and Chen JS: Treatment with exogenous hydrogen sulfide attenuates hyperoxia-induced acute lung injury in mice. Eur J Appl Physiol 113: 1555-1563, 2013. 
34. Husari AW, Khayat A, Awdeh H, Hatoum H, Nasser M, Mroueh SM, Zaatari G, El-Sabban M and Dbaibo GS: Activated protein $\mathrm{C}$ attenuates acute lung injury and apoptosis in a hyperoxic animal model. Shock 33: 467-472, 2010

35. Gong J, Liu H, Wu J, Qi H, Wu ZY, Shu HQ, Li HB, Chen L, Wang YX, Li B, et al: Maresin 1 prevents lipopolysaccharide-induced neutrophil survival and accelerates resolution of acute lung injury. Shock 44: 371-380, 2015

36. Meng X, Hu L and Li W: Baicalin ameliorates lipopolysaccharide-induced acute lung injury in mice by suppressing oxidative stress and inflammation via the activation of the Nrf2-mediated HO-1 signaling pathway. Naunyn Schmiedebergs Arch Pharmacol 392: 1421-1433, 2019.

37. Simonis FD, Juffermans NP and Schultz MJ: Mechanical ventilation of the healthy lungs: Lessons learned from recent trials. Curr Opin Crit Care 27: 55-59, 2021.

38. Staehr-Rye AK, Meyhoff CS, Scheffenbichler FT, Vidal Melo MF, Gätke MR, Walsh JL, Ladha KS, Grabitz SD, Nikolov MI, Kurth T, et al: High intraoperative inspiratory oxygen fraction and risk of major respiratory complications. Br J Anaesth 119: 140-149, 2017.

39. Crapo JD: Oxidative stress as an initiator of cytokine release and cell damage. Eur Respir J Suppl 44: 4s-6s, 2003.

40. Zhang X, Shan P, Sasidhar M, Chupp GL, Flavell RA, Choi AM and Lee PJ: Reactive oxygen species and extracellular signal-regulated kinase 1/2 mitogen-activated protein kinase mediate hyperoxia-induced cell death in lung epithelium. Am J Respir Cell Mol Biol 28: 305-315, 2003.

41. Schieber $M$ and Chandel NS: ROS function in redox signaling and oxidative stress. Curr Biol 24: R453-R462, 2014.

42. Wiegman CH, Li F, Clarke CJ, Jazrawi E, Kirkham P, Barnes PJ, Adcock IM and Chung KF: A comprehensive analysis of oxidative stress in the ozone-induced lung inflammation mouse model. Clin Sci (Lond) 126: 425-440, 2014.

43. Villegas L, Stidham T and Nozik-Grayck E: Oxidative stress and therapeutic development in lung diseases. J Pulm Respir Med 4: 194, 2014.

44. Gore A, Muralidhar M, Espey MG, Degenhardt K and Mantell LL: Hyperoxia sensing: From molecular mechanisms to significance in disease. J Immunotoxicol 7: 239-254, 2010.

45. Pagano A and Barazzone-Argiroffo C: Alveolar cell death in hyperoxia-induced lung injury. Ann NY Acad Sci 1010: 405-416, 2003.

46. Christ M, Luu B, Mejia JE, Moosbrugger I and Bischoff P: Apoptosis induced by oxysterols in murine lymphoma cells and in normal thymocytes. Immunology 78: 455-460, 1993.

47. Yamamoto H, Yamamoto Y, Yamagami K, Kume M, Kimoto S, Toyokuni S, Uchida K, Fukumoto M and Yamaoka Y: Heat-shock preconditioning reduces oxidative protein denaturation and ameliorates liver injury by carbon tetrachloride in rats. Res Exp Med (Berl) 199: 309-318, 2000.

48. Zhao X, Jin L, Shen N, Xu B, Zhang W, Zhu H and Luo Z: Salidroside inhibits endogenous hydrogen peroxide induced cytotoxicity of endothelial cells. Biol Pharm Bull 36: 1773-1778, 2013.

49. Sun Q, Wu Y, Zhao F and Wang J: Maresin 1 ameliorates lung ischemia/reperfusion injury by suppressing oxidative stress via activation of the Nrf-2-Mediated HO-1 signaling pathway. Oxid Med Cell Longev 2017: 9634803, 2017.

50. Cho HY, Jedlicka AE, Reddy SP, Zhang LY, Kensler TW and Kleeberger SR: Linkage analysis of susceptibility to hyperoxia. Nrf2 is a candidate gene. Am J Respir Cell Mol Biol 26: 42-51, 2002.

51. Kuo PC, Yu IC, Scofield BA, Brown DA, Curfman ET, Paraiso HC, Chang FL and Yen JH: 3H-1,2-Dithiole-3-thione as a novel therapeutic agent for the treatment of ischemic stroke through $\mathrm{Nrf} 2$ defense pathway. Brain Behav Immun 62: 180-192, 2017.
52. Jung KA and Kwak MK: The Nrf2 system as a potential target for the development of indirect antioxidants. Molecules 15: 7266-7291, 2010

53. Chan K and Kan YW: Nrf2 is essential for protection against acute pulmonary injury in mice. Proc Natl Acad Sci USA 96 12731-12736, 1999.

54. Iizuka T, Ishii Y, Itoh K, Kiwamoto T, Kimura T, Matsuno $\mathrm{Y}$, Morishima Y,Hegab AE,Homma S, Nomura A, et al: Nrf2-deficient mice are highly susceptible to cigarette smoke-induced emphysema. Genes Cells 10: 1113-1125, 2005.

55. Cho HY and Kleeberger SR: Noblesse oblige: NRF2 functions in the airways. Am J Respir Cell Mol Biol 50: 844-847, 2014.

56. Hirotsu Y, Katsuoka F, Funayama R, Nagashima T, Nishida Y, Nakayama K, Engel JD and Yamamoto M: Nrf2-MafG heterodimers contribute globally to antioxidant and metabolic networks. Nucleic Acids Res 40: 10228-10239, 2012.

57. Murakami A, Tanaka T, Lee JY, Surh YJ, Kim HW, Kawabata K, Nakamura Y, Jiwajinda S and Ohigashi H: Zerumbone, a sesquiterpene in subtropical ginger, suppresses skin tumor initiation and promotion stages in ICR mice. Int J Cancer 110: 481-490, 2004.

58. Willis D, Moore AR and Willoughby DA: Heme oxygenase isoform expression in cellular and antibody-mediated models of acute inflammation in the rat. J Pathol 190: 627-634, 2000.

59. Li QF, Zhu YS, Jiang H, Xu H and Sun Y: Heme oxygenase-1 mediates the anti-inflammatory effect of isoflurane preconditioning in LPS-stimulated macrophages. Acta Pharmacol Sin 30: 228-234, 2009.

60. Amata E, Pittalà V, Marrazzo A, Parenti C, Prezzavento O, Arena E, Nabavi SM and Salerno L: Role of the Nrf2/HO-1 axis in bronchopulmonary dysplasia and hyperoxic lung injuries. Clin Sci (Lond) 131: 1701-1712, 2017.

61. Hausburg MA, Banton KL, Roman PE, Salgado F, Baek P, Waxman MJ, Tanner A II, Yoder J and Bar-Or D: Effects of propofol on ischemia-reperfusion and traumatic brain injury. J Crit Care 56: 281-287, 2020.

62. Bell MT, Puskas F, Bennett DT, Herson PS, Quillinan N, Fullerton DA and Reece TB: Dexmedetomidine, an $\alpha$-2a adrenergic agonist, promotes ischemic tolerance in a murine model of spinal cord ischemia-reperfusion. J Thorac Cardiovasc Surg 147: 500-506, 2014.

63. Araújo MN, Santos CL, Samary CS, Heil LB, Cavalcanti VC, Cruz FF, Felix NS, Silva JD, Morales MM, Pelosi P, et al: Sevoflurane, compared with isoflurane, minimizes lung damage in pulmonary but not in extrapulmonary acute respiratory distress syndrome in rats. Anesth Analg 125: 491-498, 2017.

64. Zhang Y, Du H, Yu X and Zhu J: Fucoidan attenuates hyperoxia-induced lung injury in newborn rats by mediating lung fibroblasts differentiate into myofibroblasts. Ann Transl Med 8: $1501,2020$.

65. Tayman C, Cekmez F, Kafa IM, Canpolat FE, Cetinkaya M, Tonbul A, Uysal S, Tunc T and Sarici SU: Protective effects of nigella sativa oil in hyperoxia-induced lung injury. Arch Bronconeumol 49: 15-21, 2013 (In Spanish).

66. Zhang Q, Wu D, Yang Y, Liu T and Liu H: Effects of dexmedetomidine on the protection of hyperoxia-induced lung injury in newborn rats. Int J Clin Exp Pathol 8: 6466-6473, 2015.

This work is licensed under a Creative Commons Attribution-NonCommercial-NoDerivatives 4.0 International (CC BY-NC-ND 4.0) License. 